\title{
VIRTUAL LEARNING ENVIRONMENT: EFFECT OF BLENDED CLASSROOMS ON THE LISTENING SKILL IN A1 STUDENTS
}

\author{
Magali Arteaga \\ Universidad del Azuay \\ Cuenca, Ecuador \\ marteaga@uazuay.edu.ec \\ Diana Lee Rodas \\ Universidad del Azuay \\ Cuenca, Ecuador \\ dianaleerodas@uazuay.edu.ec
}

\begin{abstract}
In Ecuador, the new regulations of the government demand university undergraduate students reach B2 level before reaching $60 \%$ of the total number of credits to continue with their majors (Reglamento de Régimen Académico, 2015). The current study intends to analyze the effect of virtual classrooms in the listening skill of $A 1$ (CEFR) students as a way to enhance the learning of a foreign language by the use of the MOODLE platform of the university. The study consisted of one entire class of 28 participants. In the end, the Cohen coefficient was calculated (-1,25), a multiple linear regression $R 20.548$ was also calculated showing that the use of virtual classes is a good tool when teaching a foreign language.
\end{abstract}

Keywords: EFL classes, MOODLE, blended, listening, CEFR

\section{INTRODUCTION}

English is an international language. It is the language used in academia (Alastruè, 2015). Currently, English is spoken in many countries around the world. According to Alastruè, 300 million people use it as second language and is the official language in more than 60 countries. Governments in the world emphasize the importance of learning this language. Ecuador is not the exception. Along with the undergraduate studies, students at Ecuadorian universities have to reach the B2 level according to the Common European Framework (CEFR) (Règimen Acadèmico, 2016). In this quest, universities struggle to try to find the best ways to lead their students accomplish such goal.

Given this importance in helping students achieve the B2 level, the government support any strategy or planning that can help students improve their level of English is more than welcome. The process of learning a language 
involves four skills: listening, speaking, reading and writing. Listening is one of the four skills that make up the process of language learning (Pourhosein $\&$ Banoun, 2016). There are many reasons for this. First of all, motivation, students always want to understand what native speakers are saying (Vandergrift, 2007). Second, input, listening helps in the acquisition of a language and in its development (Rost, 1994; Hamouda, 2013). Third, proficiency, listening is closely related to proficiency in speaking (Rost, 2002).

Given the positive benefits that the listening skill brings to class, this study pretended to shed light on the impact that the MOODLE platform has in the development of the listening skill in an A1 EFL class in Cuenca-Ecuador.

This study took place in Cuenca, a town located in the highland region of Ecuador in South America. Cuenca is an intercultural place where $80 \%$ of its population consider themselves as mestizos (people of mixed racial or ethnic ancestors). Spanish is the official language.

At university where this study was designed and accomplished, students take five English hours of class per week to get to the B2 level according to the Common European Framework (CEFR). It is up to students to take an English placement test at the beginning of their studies to put them in the right group in accordance with the CEFR level.

The English curriculum, however, is subject to a deep analysis to further studies in order to fulfill the requirements of the law. Therefore, the participants of the study belonged to the last group of students taking English under the structure of three levels: level 1 with an exit level of A2-, level 2 with an exit level of A2 and level 3 with an exit level of A2+. The students who participated in the present study were in their first English level.

As for their socio-economic background, 100\% were mestizos coming from urban and rural areas. The course lasted 80 hours. Students belong to two majors at the Faculty of Philosophy in the university: Early Education and Basic Education.

Typically, they had not had the opportunity to travel abroad to learn a foreign language nor had they received long English instruction in their high school or private educational institutions. Only one participant had lived in an English speaking country when she was a child. 
Arteaga \& Rodas, Virtual Learning Environment: Effect of Blended Classrooms ...

As this is the last program run for $\mathrm{A} 2+$, the authorities decided to design the program under a blended format. Therefore, the project consisted of 3 hours of face-to-face classes and 3 hours of autonomous work. That is, work done at home or elsewhere, but not in class time. The decision was made upon the reality that many students live nowadays. Research has shown that the current university student, contrary to the old one, works full time, and attends more night courses (Munro, 2011). Therefore, the university felt that instead of having students fail because of missing many hours of class, they should be given the opportunity to work at home and at their own pace, specifically by a blended style of class.

The word 'blended' means that a student learns both from face-to-face and technology based classes. In a world where digital literacy is necessary, creating a virtual learning environment (VLE) can be a challenge for teachers, as they need to be aware of all the accessible devices to students and think about the objectives they have to achieve in a Virtual learning environment. There is a belief in English teachers that nothing can be learned without the help of a teacher.

However, in a demanding world where information can be reached at one single click of a finger, the time given to students for on-campus learning needs to be strictly designed so as to have students foster the skills which are absolutely important in face-to-face classes as current students need the opportunity to work and study at the same time. So, if there is no time to see students to encourage the learning process, how can a teacher enhance learning? Thus, the purpose of this study was to check the effect that blended classes have on the listening skill in an EFL class.

The study consisted on designing a virtual class with online components based on the DADDIE model. Eight units were included in the MOODLE platform of the university. These units were designed taken into consideration the prescribed book: Interchange 1A (Richards, Hull \& Proctor, 2013). Students were assigned 3 hours of face-to-face classes, with a total of 180 hours in the academic period of March-July. Work on the platform had a design of 3 hours additional to the face-to-face classes. The researchers 
worked with 29 students in total. Unfortunately, the university where the study took place changed the curriculum of English, and all majors were restructured depending on the demands of the LOEI (Ley Orgànica de Educaciòn Superior, as per its Spanish acronyms), which is the institution in charge of regulating careers of all universities in Ecuador. As it is the only class working with this new type of design, the researchers worked with one whole group. The process lasted a total of 16 weeks during the academic period of MarchAugust, 2017.

At present, educators seek to encourage communicative competence in local and foreign languages (Yang, Chuang, Li \& Tseng, 2013). These authors consider that given the importance of English language skills in the $21^{\text {st }}$ century all efforts put in enhancing its learning are worth trying. As listening represents an input skill that helps "awaken awareness of the language" (Renukadevi, 2014). Therefore, learning to listen in a foreign language, improves the ability to acquire the language.

According to a study by Yu \& Wang (cited by Yang, 2013), studentbased teaching is a key to acquiring listening and speaking skills in the English language. Other study carried out by Yuin, Huang \& Shadiev (2014) deals with the design of learning activities based on a Cellular Learning System for the development of listening and speaking skills in English as a Foreign Language (EFL). The study explored students' perceptions about learning activities and systems while using cell phones. Additionally, practices related to student language proficiency were analyzed.

Students were found to have positive perceptions about this type of learning; therefore, they felt motivated to practice English skills using the cell phone system. The results showed that the abilities of speaking and listening using cellular devices had correlation with their English levels. For example, students who carefully selected their peers did better than others who did not. Additionally, it was found that the better the students were in English language learning, the fewer peers they chose. 
Arteaga \& Rodas, Virtual Learning Environment: Effect of Blended Classrooms ...

Guangying (2014) relates to the blended learning approach to teaching English as a foreign language in China. The author of this study investigated the effectiveness of the Blended approach for the improvement of students' listening and speaking skills. The results of the research indicated that listening and speaking skills improved. Compared to the traditional teaching method, the blended learning approach was effective in promoting teacher and student initiative and encouraging student autonomy.

Similarly, in a study by Wise, Speer, Marbouti \& Hsiao (2011) mention that it is important to note that online listening differs in different specific forms of listening in in-person conversations. Generally, in online discussions students have active control over feedback as well as when and for how long to do so. Comments are not necessarily received in the order they were made and students decide to focus their attention on a specific part of the discussion instead of listening to all parties indiscriminately. There are also opportunities not available in person-to-person situations such as taking time to reflect before responding and revisiting comments from the earlier parts of the conversation (Speer, Marbouti \& Hsiao, 2011).

Smith and Ragan (1995) made the design called ADDIE, which was used for the present study, with the variation of a $D$ at the beginning, which stands for definition of the expected learning outcomes.

The pedagogy of blended classrooms advocates to a constructivist approach (Attwell \& Hughes, 2010). Therefore, the core of a blended class is to move away from the teacher-directed instruction, which mainly represents behaviorism. Therefore, students will construct their own knowledge in interaction with a community, known as communities of practice. Wenger (1998) considers that the communities of practice are a good way to learn because human beings pursuit social relations. This author considers that a community of practice is a group of people that are engage in the pursuit of something, which in this case is learning English through a virtual class. 


\section{DISCUSSION}

To assure the research ethical practice, all the participants signed a consent form, which was written in Spanish. The consent form guaranteed that the research would not harm or affect the participants in their grades for being part of the study.

The intervention process lasted a total of 16 weeks. Throughout this time, students received classes with a platform. The format of the class was the following: 3hours of face-to-face classes a week and 3 hours of online components. The prescribed book used was Interchange $1 \mathrm{~A}$, from which some listening passages were uploaded in the platform after asking for the corresponding permission. Students first took the placement test, after they took the pre-test and immediately registered in the virtual class of the university. There were 8 units in total. Each unit was designed with listening practice only. There were videos included in it. All the listening exercises were designed in the same platform, so that students would not need printings. The material used was authentic. It included videos, listening exercises from the prescribed book, multiple choice exercises to check students 'understanding, songs and many other listening exercises. All the tests used in this research were piloted before being administered to the experimental. The Cambridge Placemen Test (CEPT) was used to check the students level of English. The licenses were bought to Cambridge directly. The test has an online format.

The pre-test was taken from the book Passages. Only the listening part of the test was used. The test was piloted with a group of students different from the intervened one. The post-test was the same as the pre-test. The post-test was applied 5 months after the pre-test. In this way, it is disregarded problems with memorization. The sample consisted of 28 students from the school of Early Education, which belongs to the Faculty of Philosophy in a private university in Azuay.

The participants were between 18 and 23 years of age, the average age was 20 years (s.d. 1,5). All students had similar levels of English proficiency, as well as previous experiences and similar learning processes. To establish 
Arteaga \& Rodas, Virtual Learning Environment: Effect of Blended Classrooms ...

that the students had a similar level of English, the Cambridge English Placement Test (CEPT) were given. The results of the placement test were:

Table 1 . The results of CEPT

\begin{tabular}{ccc}
\hline CEPT level & $\mathbf{N}$ & $\%$ \\
\hline- A1 & 5 & 17,9 \\
\hline A1 & 16 & 57,1 \\
\hline A2 & 6 & 21,4 \\
\hline B1 & 1 & 3,6 \\
\hline Total & 28 & 100,0 \\
\hline
\end{tabular}

The results show that most students were in the A1 level. This helped the researchers organize the platform with material belonging to the A2- level.

\section{Intervention.}

The evaluation of the listening skill before and after the intervention was done by means of a test taken from the Cambridge book Passages. The instrument consisted of 4 listening parts. Each section evaluated the listening skill through a multiple-choice question. The evaluation was measured with a score of 0 to 20 points.

$\mathrm{H}_{0}=$ The listening skill in A1 (CEFR) EFL students does not improve through a vistual leaning environment: MOODLE.

$\mathrm{H}_{1}=$ The listening skill in A1 (CEFR) EFL students improves through a virtual learning environment: MOODLE.

To analyze the results, the researchers used the SPSS software and the statistics analysis of Shapiro-Wilk. It was determined that the difference between the pre-test and the post-test was normally distributed (Shapiro-Wilk test $0.9661,28 \mathrm{gl}, \mathrm{p}$ 0.377). Therefore, the researchers used the student's $\mathrm{t}-$ test statistic for repeated samples. In order to know the statistical strength of the results, an effect size analysis (Cohen, 1992) of the differences between the means before and after the intervention on the standard deviation was performed. 


\section{EduLite}

Journal of English Education, Literature, and Culture

In addition to comparing the pre and post intervention situation, a multivariate linear regression was generated, taking as a dependent variable the post-evaluation and as the independent variable the pre-test and the results of CEPT.

The level of statistical significance established to accept or reject the hypothesis that students have significantly improved. The alpha result was 0.05 .

\section{Findings}

On average, the students obtained a level of 6.6 points (s.d 3.25) in the listening skill before the intervention process. Although this value is far from the maximum value of the test, which was 20 , in the course of the intervention it increased by 1.32 (s.d 2.16) points to finally reach a level with an average value of 7.93 points (SD 2.93).

Table 2. Difference between the pre and post-tests

\begin{tabular}{lllllll}
\hline Evaluation & Pre-test & Post-test & Difference ta & gl & $\begin{array}{l}\text { p } \\
\text { value }\end{array}$ \\
\hline Mean & 6,61 & 7,93 & 1,32 & - & & \\
Standard Dev. & 3,25 & 2,93 & 2,16 & 3,235 & 0,003 \\
Standard Error & 0,61 & 0,55 & 0,41 & & \\
\hline
\end{tabular}

1. ad Cohen -1.25 , effect size 0.53

The differences between the pre-test and the post-test are shown. They reveal a different behavior in the students listening test before and after the intervention. 
Arteaga \& Rodas, Virtual Learning Environment: Effect of Blended Classrooms ...

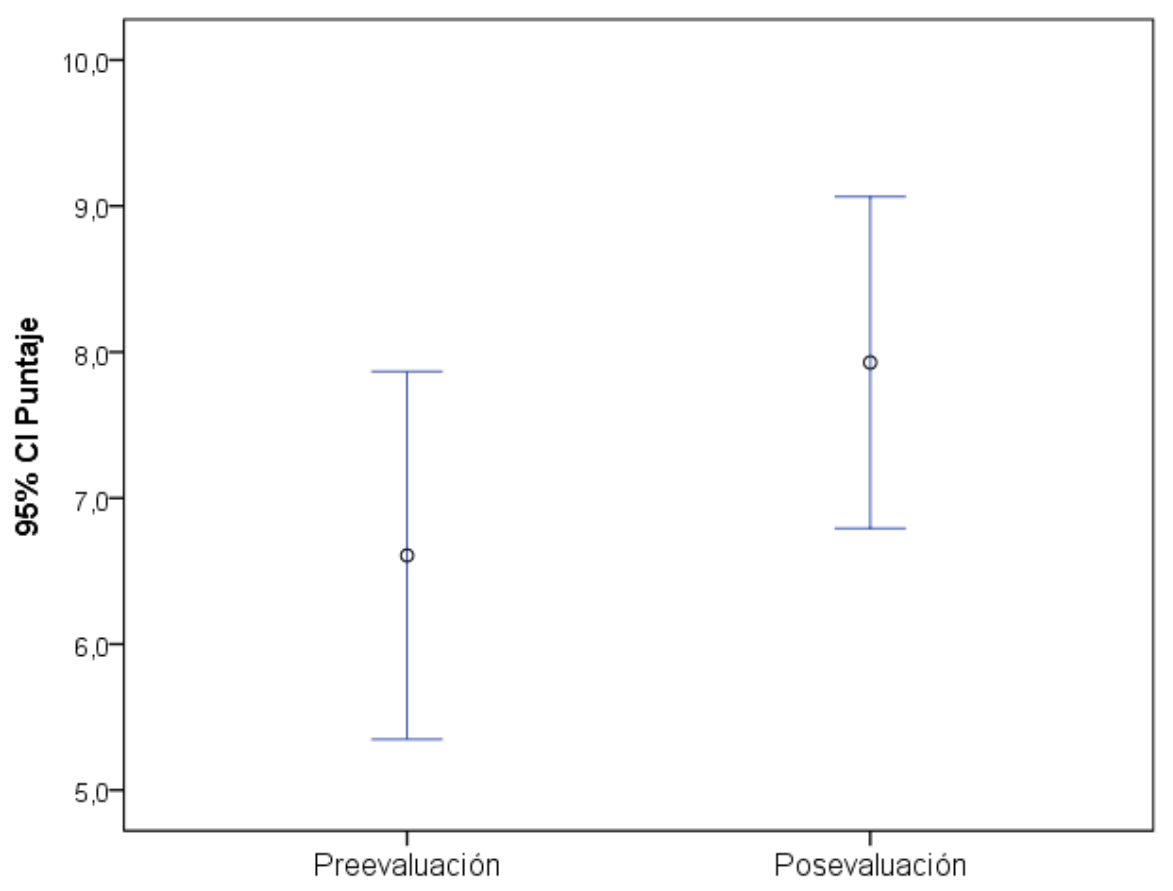

Figure 1. The result of multiple linear regression

In addition, a multiple linear regression (R2 0.548, F 17.358, 2gl, p value 0.000) was generated to show if the level of English students by using the CEPT, together with the pre-test, influences the listening results without being able to verify this assumption. In fact, only the pre-test was considered as a predictive variable of the post-test $(p<0.05)$. In this analysis, the CEPT would not change the increase obtained after the intervention process $(p \geq 0.05)$. In other words, all students improved, or at least maintained their listening skill, regardless their level on English. The results show that all participants had the opportunity to benefit from their listening level thanks to the intervention.

Table 3. The result of Pretest

\begin{tabular}{llllll}
\hline & \multicolumn{2}{l}{$\begin{array}{l}\text { Non- } \\
\text { standardized } \\
\text { coefficient }\end{array}$} & $\begin{array}{l}\text { Standarized } \\
\text { coefficient }\end{array}$ & \\
\cline { 2 - 5 } & $\mathrm{B}$ & $\begin{array}{l}\text { Error } \\
\text { estándar }\end{array}$ & Beta & $\mathrm{t}$ & \\
\hline (Constant) & 3,311 & 0,875 & & Sig. \\
Pre-test & 0,649 & 0,139 & 0,719 & 3,783 & 0,001 \\
CEPT & 0,299 & 0,613 & 0,075 & 4,661 & 0,000 \\
\hline
\end{tabular}

Note: Dependent Variable: Post-test 
The analysis of the instrumentation used in the study allowed the researchers to consider that this study can be repeated in other places. However, it would be inaccurate to say that it can be a hundred per cent reliable due to certain limitations such as the number of the participants and their background. The university where the study took place is a private university in Ecuador. Consequently, the researchers suggest applying the intervention to participants who study in a public university for results that are more generalizable.

\section{CONCLUSION}

The results of the statistical analysis showed that direct training on the listening skill by means of the MOODLE platform had a positive effect on the students listening skill. There is a close relationship between training on listening skill by means of the MOODLE platform of the university and the student’s listening skill.

This finding concurs with the literature review about blended classrooms and communities of practice. Given the positive results, the researchers believe that the use of virtual classes enhances listening comprehension problems most of the EFL students face in class time in Ecuador. Besides, the use of the platform enhanced the responsibility of students, as they had to work by themselves in the platform. Most students accomplished their tasks on time and the two who did not do it, approached the teacher with an explanation on it.

\section{REFERENCES}

Alastrué, R. (2015). Debates and discourses on English as an Academic and research language. In Alastrué, R.P. \& Perez-Llantada, C. (Eds), English as a scientific and research language: Debates and discourses: English in Europe. (Vol, 2, pp3-8), Walter de Gruyter: Boston: Walter de Gruyter Alastrué, R.P. \& Perez-Llantada, Carmen.

Arnau, J. (1997). Diseños de investigación aplicados en esquemas. Barcelona: Publicacions Universitat de Barcelona. 
Arteaga \& Rodas, Virtual Learning Environment: Effect of Blended Classrooms ...

Attwell, G. \& Hugghes, J. (2010). Pedagogic theories and the use of technologies for learning and their implications. Pedagogy approaches for using technology for learning, pp. 15-25 UK: Lifelong learning.

Cohen, J. (1992). Quantitative methods in psychology, a power primer. Psychological bulletin, 112, 155-159.

Hamouda, A. (2013). An investigation of listening comprehension problems encountered by Saudi students in the EL listening classroom. International Journal of Academic Research in Progressive Education and Development. 2(2), 113-155.

Hernández, R., Fernández, C., \& Baptista, P. (2010). Metodología de la Investigación (Quinta ed.). México D.F.: McGraw Hill.

Munro, L. (2011) 'Go boldly, dream large!': the challenges confronting non-traditional students at university. Aust. J. Educ. 55, 115131 .

Pourhosein, A, \& Banou, N. (2016). The significance of the English comprehension. Theory and practice language studies. 6(8), pp. 1670-1677.

Renukadevi, D. (2014). The role of listening in language acquisition; the challenges \& strategies in teaching listening. International Journal of Education and Information Studies. 4(1), pp.59-63.

Richards, J., Hull, J. \& Proctor, S. (2013). Interchange 1A. Cambridge: Cambridge university press.

Reglamento de Régimen Académico (2015). Articulo 30. Retrieved from: http:/ / www.utpl.edu.ec/sites/default/files/documentos/reglame nto-de-regimen-academico-2015.pdf

Rost, M. (2011). Semantic processing. In Candlin, C. \& Hall, R. (Eds) Teaching and researching listening. pp. 53-76. Harlow: Pearson.

Smith, P. L. \& Ragan, T.J. (1999). Instructional design. Hoboken, NJ: John Wiley \& Sons.

University of Rhode Island (2017). http://web.uri.edu/online/what-isblended-teaching/

Vandergrift, L. (1997). The comprehension strategies of second language (French) learners: A descriptive study. Foreign Language Annals, 30(3), 387-409 . doi: 10.1111/j.1944-9720.1997.tb02362.x 


\section{EduLite}

Journal of English Education, Literature, and Culture

Volume 3, Number 1, February 2018

Wenger, E. (1999). Meaning. Communities of practice: Learning, meaning and identity. Pp. 51-71. Cambridge: Cambridge University Press. 